\title{
Korelasi Antara Panjang Tulang Humerus Dengan Tinggi Badan Suku Batak Di Universitas HKBP Nommensen Medan
}

\author{
Roy Abednego Purba1, Saharnauli Verawaty Simorangkir ${ }^{2}$, Rebecca Rumesty Lamtiar ${ }^{3}$ \\ ${ }^{1}$ Mahasiswa, Fakultas Kedokteran Universitas HKBP Nommensen \\ ${ }^{2}$ Departemen Anatomi Fakultas Kedokteran Universitas HKBP Nommensen \\ ${ }^{3}$ Departemen Fisiologi Fakultas Kedokteran Universitas HKBP Nommensen \\ Korespondensi: Saharnauli Verawaty Simorangkir, Email: saharnauli@uhn.ac.id
}

\begin{abstract}
Background: Body height is one of the data in forensic identification process. The process of measuring body height can be difficult if the bones or the body part are not completely found. Estimation of body height can be easier by measuring the lenght of a bone. The analysis of humerus lenght with body correlation can support to determine the formula of estimating body height based on humerus length.
\end{abstract}

Objective: This study aimed to determine the correlation between humerus lenght and body height on Bataknese in Universitas HKBP Nommensen.

Method: This is a descriptive analytic study with cross sectional design. The sample was 72 Bataknese students, lectures, and employees in Universitas HKBP Nommensen Medan, which consist of 27 male and 45 female according to inclusion and exclusion criteria. Sampling was done by purposive sampling. Data analysis was conducted by univariate method to describe the characteristics of the subjects, normality test was using the Kolmogorov-Smirnov and Shapirowilk test and bivariate analysis was using the Pearson and Spearman test methods to determine the correlation between humerus lenght and body height variables.

Results: The results showed a strong correlation between humerus lenght and body height in the Bataknese with correlation coefficient value $r=0,784(p<0,05)$. Based on gender, male have a weak and insignifant correlation strength with correlation coefficient $r=0,449(p>0,05)$ while women have strong and significant correlation with correlation coefficient $r=0,771(p<0,05)$.

Conclusion: There was a strong correlation between humerus lenght and body height on Bataknese in Universitas HKBP Nommensen Medan.

Keywords: Humerus, Body Height, Bataknese

\begin{abstract}
Abstrak
Latar belakang: Tinggi badan merupakan salah satu data pada proses identifikasi forensik. Proses pengukuran tinggi badan dapat sulit dilakukan jika tulang atau potongan tubuh yang ditemukan tidak utuh. Estimasi tinggi badan tersebut dapat dipermudah dengan mengukur panjang sebuah tulang. Analisa korelasi panjang tulang humerus dengan tinggi badan dapat mendukung dalam menentukan formula estimasi tinggi badan berdasarkan panjang tulang humerus.
\end{abstract}

Tujuan: Studi ini bertujuan untuk mengetahui korelasi antara panjang tulang humerus dengan tinggi badan suku Batak di Universitas HKBP Nommensen Medan.

Metode: Studi ini adalah studi analitik deskriptif dengan desain cross sectional. Sampel studi adalah mahasiswa, dosen, dan pegawai bersuku Batak di Universitas HKBP Nommensen Medan sejumlah 72 orang terdiri dari 27 
orang laki-laki dan 45 orang perempuan yang memenuhi kriteria inklusi dan eksklusi. Pengambilan sampel dilakukan dengan cara purposive sampling. Analisa data pada studi ini dilakukan dengan cara univariat untuk mendeskripsikan karakteristik subjek, uji normalitas menggunakan uji Kolmogorov-Smirnov dan Shapirowilk serta analisis bivariat menggunakan metode uji Pearson dan Spearman untuk mengetahui korelasi antara variabel panjang tulang humerus terhadap variabel tinggi badan.

Hasil: Hasil didapatkan korelasi kuat antara panjang tulang humerus dengan tinggi badan pada suku Batak dengan nilai koefisien korelasi $r=0.784(p<0.05)$. Berdasarkan jenis kelamin laki-laki memiliki kekuatan korelasi yang lemah dan tidak signifikan dengan koefisien korelasi $r=0.449(p>0.05)$ sedangkan perempuan memiliki korelasi kuat dan signifikan $r=0.771(p<0.05)$.

Kesimpulan: Terdapat korelasi kuat antara panjang tulang humerus dengan tinggi badan suku Batak di Universitas HKBP Nommensen Medan.

\section{Kata Kunci: Humerus, Tinggi Badan, Suku Batak}

\section{Pendahuluan}

Proses identifikasi forensik adalah upaya pengenalan individu berdasarkan ciri-ciri ataupun sifat-sifatnya yang membedakannya dari individu lainnya. Pada penerapannya identifikasi forensik dilakukan pada korban-korban bencana ataupun kasus-kasus kriminal yang membutuhkan identifikasi. Upaya-upaya yang dapat dilakukan dalam identifikasi forensik adalah pengukuran data-data post-mortem yang didapat pada korban. Data-data tersebut dapat berupa tinggi badan, warna kulit, warna rambut, bentuk hidung, telinga, dagu , tanda pada badan ,panjang dan lebar kepala , sidik jari, dan DNA. ${ }^{1}$ Data post-mortem tersebut akan dicocokkan dengan data ante-mortem yang ditelusuri melaui keluarga ataupun kerabat korban.

Tinggi badan merupakan salah satu data sekunder pada identifikasi forensik yang dilakukan oleh tim Disaster Victim Investigation. ${ }^{2}$ Pada umumnya pengukuran tinggi badan korban pada proses identifikasi forensik adalah hal yang mudah, jika kondisi tubuh nya utuh, ataupun potongan-potongan tubuhnya lengkap, sehingga dapat disusun dan dilakukan pengukuran tinggi badan. Tetapi pada kejadian-kejadian tertentu seperti mutilasi dan bencana alam lainnya yang menyebabkan kondisi potongan jenazah yang ditemukan tidak lengkap, akan sedikit menyulitkan dalam proses identifikasi.

Upaya perkiraan tinggi badan berdasarkan ukuran tulang atau potongan tubuh korban bukanlah hal yang baru. Umumnya pada perkiraan tinggi badan tersebut tulang yang digunakan adalah tulang-tulang panjang dikarenakan ukuran yang relatif lebih besar yang mempermudah dalam proses pengukurannya, dan lebih signifikan mewakili tinggi badan seseorang. ${ }^{3,4}$ Formula yang dapat digunakan untuk memperkirakan tinggi badan seseorang berdasarkan tulang panjang( humerus, radius, ulna , femur , tibia, fibula) dinamakan formula Trotter and Glesser.1,4 Sampel yang dipakai untuk menetapkan formula ini adalah berasal dari ras mongoloid dari berbagai suku (laki-laki) di India oleh karena itu penggunaannya untuk perkiraan tinggi badan pada orang Indonesia dan dengan suku-suku yang beragam perlu pertimbangan lagi. ${ }^{1,5}$ Sejauh ini belum ada formula khusus yang digunakan untuk memperkirakan tinggi badan berdasarkan tulangtulang panjang dari penelitian yang dilakukan di Indonesia. ${ }^{1}$
Provinsi Sumatera Utara, terdapat delapan kelompok etnis atau suku bangsa asli yang mendiami provinsi ini yaitu Melayu, TobaSamosir, Mandailing-Angkola, Karo, Simalungun, Dairi, Pakpak Barat, dan Nias. Kedelapan suku tersebut telah berbaur di Sumatera Utara, ditambah adanya suku-suku pendatang seperti Jawa, Minang, Banjar, Aceh, dan lain-lain, termasuk etnis India dan Tionghoa. Mayoritas suku terbesar yang mendiami provinsi Sumatera Utara adalah suku Batak yang mencapai $44.75 \% .{ }^{6}$ Studi mengenai panjang tulang dengan tinggi badan memang sudah pernah dilakukan. Tulang yang digunakan kebanyakan adalah tulang panjang yang salah satu nya adalah tulang humerus yang dilakukan Yudhyasari pada tahun 2015 memperoleh hasil korelasi terkuat dengan sampel yang lebih besar dibandingkan penelitian yang lainnya. ${ }^{7}$ Tetapi studi mengenai hubungan panjang tulang humerus pada suku Batak masih jarang dilakukan . Berdasarkan latar belakang diatas, peneliti ingin melakukan penelitian untuk melihat korelasi antara panjang tulang humerus dengan tinggi badan pada suku Batak.

\section{Metode}

Studi ini merupakan studi analitik deskriptif dengan desain crosssectional yang dilaksanakan pada Desember 2019-Januari 2020. Variabel pada studi ini adalah panjang tulang humerus dan tinggi badan dengan skala numerik. Populasi pada studi ini adalah seluruh mahasiswa, dosen dan pegawai Universitas HKBP Nommensen. Sampel berjumlah 72 yang terdiri dari 27 orang lakilaki dan 45 orang perempuan yang memenuhi kriteria inklusi dan eksklusi. Cara pemilihan sampel pada studi ini dilakukan dengan metode purposive sampling. Kriteria inklusi dan eksklusi pada studi ini adalah subjek bersedia menandatangani informed consent dengan berusia minimal 21 tahun pada saaat penelitian dilaksanakan, dominan menggunakan tangan kanan, berasal dari suku Batak tanpa pecampuran selama dua generasi, tidak memiliki riwayat trauma dan tindakan medis yang memengaruhi panjang tulang lengan atas dan tinggi badan, dan tidak memiliki cacat lahir. Pengukuran tinggi badan dilakukan menggunakan instrumen microtoise dengan titik puncak kepala (vertex) dan titik terendah tulang kalkaneus (heel). Pengukuran humerus dilakukan pada humerus kiri, untuk meminimalisir perbedaan aktivitas menggunakan tangan kanan yang dapat mempengaruhi panjang tulang dan massa otot, sehingga dapat menjadi bias pada saat pengukuran. Pengukuran panjang tulang humerus menggunakan 
kaliper geser, dimana titik proksimal pengukuran terletak pada acromion, dan menentukan titik distal dengan menarik garis khayal secara vertikal sepanjang $2 \mathrm{~cm}$ di bawah epikondilus medial, sedangkan titik yang lain dengan menarik garis khayal sepanjang $1 \mathrm{~cm}$ di bawah epikondilus lateral, kemudian ditarik garis khayal yang menghubungkan kedua ujung garis sebelumnya dan menentukan titik tengahnya sebagai titik pengukuran distal. ${ }^{8}$ Pengukuran dilakukan pada pukul 08.00-10.00 pagi pada seluruh subjek untuk menghindari diurnal variation.9-11 Data yang telah didapat diolah secara univariat untuk mendapatkan deskripsi karakteristik subjek dan variabel. Uji normalitas dilakukan menggunakan uji Kolmogorov-Smirnov dan Shapirowilk. Analisis bivariat dilakukan untuk mengetahui korelasi antara kedua variabel menggunakan uji Pearson dan Spearman.

\section{Hasil}

Uji univariat pada sampel penelitian ini menghasilkan deksripsi sampel berdasarkan rentang usia, jenis kelamin, dan pekerjaan. Rentang usia terbanyak pada penelitian ini berada pada usia 2125 tahun $(94,44 \%)$ dengan jenis kelamin perempuan $(62,50 \%)$ dan status pekerjaan mahasiswa $(98,61 \%)$ (Tabel 1). Pada deskripsi karakteristik sampel tidak didapat sampel dengan status pekerjaan dosen atau tenaga pengajar, dikarenakan tidak memenuhi kriteria minimal dan maksimal yang ditetapkan pada studi ini.

Tabel 1. Karakteristik Sampel

\begin{tabular}{lccc}
\hline \multicolumn{1}{c}{ Variabel } & Kategori & Jumlah & Persentase \\
\hline Usia & $21-25$ & 68 & $94.44 \%$ \\
& $26-30$ & 4 & $5.55 \%$ \\
Jenis & Perempuan & 45 & $62.50 \%$ \\
Kelamin & Laki-laki & 27 & $37.50 \%$ \\
Status & Mahasiswa & 71 & $98.61 \%$ \\
Pekerjaan & Pegawai & 1 & $1.38 \%$ \\
\hline
\end{tabular}

Deskriptif variabel didapat bahwa rerata tinggi badan dan panjang humerus suku Batak laki-laki lebih tinggi dibandingkan pada perempuan (Tabel 2). Hasil analisis korelasi antara kedua variabel dilakukan secara keseluruhan dan berdasarkan jenis kelamin. Berdasarkan jenis kelamin, laki-laki memperoleh hasil korelasi sedang dan tidak signifikan, perempuan memperoleh hasil korelasi kuat dan signifikan, sedangkan secara keseluruhan memperoleh hasil yang kuat dan signifikan (Tabel 3). Uji normalitas pada variabel berdasarkan jenis kelamin terdistribusi secara normal sehingga uji korelasinya menggunakan uji Pearson. Variabel tinggi badan keseluruhan subjek tidak terdistribusi secara normal maka untuk mengetahui korelasi antar variabel nya menggunakan uji Spearman. Panjang tulang humerus yang diukur pada penelitian ini adalah panjang tulang humerus kiri, sesuai dengan kriteria inklusi dan eksklusi.

Tabel 2. Statistik Deskriptif Berdasarkan Jenis Kelamin

\begin{tabular}{ccccc}
\hline \multirow{2}{*}{ Variabel } & \multicolumn{2}{c}{ Laki-laki } & \multicolumn{2}{c}{ Perempuan } \\
\cline { 2 - 5 } & Rerata & SD & Rerata & SD \\
\hline $\begin{array}{c}\text { Tinggi } \\
\text { Badan }\end{array}$ & 170.2 & 4.27 & 153.4 & 5.50 \\
$\begin{array}{c}\text { Panjang } \\
\text { Humerus }\end{array}$ & 30.24 & 1.31 & 27.87 & 1.53 \\
\hline
\end{tabular}

\section{Pembahasan}

Hasil uji univariat pada penelitian ini didapat rerata tinggi badan laki-laki suku Batak 170,2 cm dan 153,3 cm pada perempuan. Rerata tinggi badan laki-laki suku Batak pada penelitian ini termasuk pada kategori tinggi menurut kriteria martin. ${ }^{12} \mathrm{Hal}$ ini tidak sesuai dengan rerata tinggi Badan laki-laki suku Batak pada penelitian Indrani di Lampung yang memeroleh hasil 169,7 cm yang berada pada kategori sedang. Perbedaan tersebut dimungkinkan terjadi oleh karena faktor genetik, gizi, dan lingkungan yang memengaruhi pertumbuhan panjang tulang, walaupun berasal pada ras yang sama. ${ }^{12}$

Tabel 3. Hasil Uji Korelasi

\begin{tabular}{cccc}
\hline \multirow{2}{*}{ Variabel } & \multicolumn{3}{c}{ Nilai $\mathbf{r}$} \\
\cline { 2 - 4 } & $\begin{array}{c}\text { Laki-laki } \\
(\boldsymbol{p} \text {-value })\end{array}$ & $\begin{array}{c}\text { Perempuan } \\
(\boldsymbol{p} \text {-value })\end{array}$ & Total \\
\hline Tinggi Badan & 0.449 & 0.771 & 0.784 \\
$\begin{array}{c}\text { dengan Panjang } \\
\text { Humerus }\end{array}$ & $(0.190)$ & $(0.000)$ & $(0.000)$ \\
\hline
\end{tabular}

Uji korelasi studi ini memperoleh hasil kekuatan korelasi yang kuat dan signifikan secara keseluruhan $r=0,784(p<0,05)$ antara tulang humerus kiri dengan tinggi badan. Hasil yang sama juga diperoleh pada suku Bali di Lampung oleh Thare $r=0,801(p<0,05)$ dan Yudyasari pada mahasiswa fakultas kedokteran UNS $r=0,736(p<$ 0,05 ) menggunakan tulang humerus kiri.7,13 Korelasi secara keseluruhan antara panjang tulang humerus dengan tinggi badan suku Batak pada penelitian ini tidak sesuai jika diklasifikasikan berdasarkan jenis kelamin. Jenis kelamin laki-laki memperoleh hasil kekuatan korelasi yang lemah dan tidak signifikan $r=0,449$ $(p>0,05)$, sedangkan pada perempuan kekuatan korelasi kuat dan signifikan $r=0,771 \quad(p<0,05)$. Perbedaan hasil berdasarkan jenis kelamin tersebut dapat disebabkan jumlah subjek yang didapat lebih sedikit pada laki-laki dibandingkan perempuan sehingga pada saat dilakukan pengujian statistik memperoleh hasil kekuatan korelasi yang lebih rendah dan tidak signifikan.

Studi mengenai korelasi panjang tulang terhadap tinggi badan suku Batak, sudah pernah dilakukan. Meskipun beberapa studi tersebut menggunakan tulang yang berbeda, hasil yang didapatkan relatif sama. Bagus di UMSU memperoleh hasil kekuatan korelasi yang kuat dan signifikan $r=0,867 \quad(p<0,05)$ secara keseluruhan menggunakan tulang ulna kiri. Jika dilihat berdasarkan jenis kelamin pada penelitian Bagus memperoleh hasil kekuatan korelasi $r=0,761(p<0,05)$ pada laki-laki dan $r=$ $0,641(p<0,05)$ pada perempuan. ${ }^{6}$ Penelitian serupa juga sudah dilakukan oleh Indrani pada suku Batak di Lampung menggunakan tulang telunjuk kiri yang memperoleh hasil kekuatan korelasi $r=$ $0,613(p<0,05)^{14}$.

\section{Kesimpulan}

Pada studi ini didapatkan korelasi yang kuat antara panjang tulang humerus dengan tinggi badan pada suku Batak. Hasil korelasi pada penelitian ini dan penelitian-penelitian lainnya diharapkan dapat digunakan untuk menemukan formula estimasi tinggi badan suku Batak menggunakan panjang suatu tulang dengan tujuan untuk mempermudah proses identifikasi tinggi badan pada keadaan dimana tulang belulang yang ditemukan tidak lengkap. 


\section{Ucapan Terima Kasih}

Peneliti mengucapkan banyak terima kasih kepada Universitas HKBP Nommensen, responden yang sudah bersedia mengikuti penelitian ini, dan khususnya terhadap dosen pembimbing serta asisten penelitian yang sudah berkontribusi dalam menyelesaikan penelitian ini.

\section{Daftar Pustaka}

1. Amir A. Rangkaian IImu Kedokteran Forensik. 2 ed. Jakarta: Ramadhan; 2005. 178-202, 192-193 hal.

2. Prawestiningtyas E, Algozi AM. Forensic identification based on both primary and secondary examination priority in victim identifiers on two different mass disaster cases. J Kedokt Brawijaya. 2009;25(2):88-94.

3. Idries AM. Pedoman IImu Kedokteran Forensik. 1 ed. Jakarta: Binarupa Aksara; 1997. 45 hal.

4. Devison RJ. Penentuan tinggi badan berdasarkan panjang lengan bawah [tesis]. Universitas Sumatera Utara. 2009.

5. Gocha TP, Vercellotti G, McCormick LE, Deest TL Van. Formulae for estimating skeletal height in modern South-East Asians. J Forensic Sci. 2013;58(5):1279-83.

6. Nugraha BP. Korelasi antara panjang tulang ulna terhadap tinggi badan pada mahasiswa suku Batak di Fakultas Kedokteran Universitas Muhammadiyah Sumatera Utara [skripsi]. Universitas Muhammadiyah Sumatera Utara. 2017.
7. Yudyasari CA. Estimasi tinggi badan menggunakan panjang tulang humerus pada mahasiswa Prodi Pendidikan Dokter FK UNS Semester VII [skripsi]. Universitas Sebelas Maret. 2015

8. Prateek G, Shalini G, Anupama M, Kalyan K, Chakravarthi. Estimation of height using length of humerus in adult North Indian population-an anthropometric study. Int J Sci Res. 2013;2(10):1-3.

9. Amit K, Srivaskata AK, Verma AK. Estimation of stature by percutaneous measurements of distal half of upper limb (forearm \& hand). J Indian Acad Forensic Med. 2010;32(4):325-8.

10. Ahmed AA. Estimation of stature using lower limb measurements in Sudanese Arabs. J Forensic Leg Med. 2013; 20:483-8.

11. Chikhalkar BG, Mangaonkar AA, Nanandkar SD, Peddawad RG. Estimation of stature from measurements of long bones, hand and foot dimensions. $J$ Indian Acad Forensic Med. 2010;32(4):329-31.

12. Indriati E. Antropologi Forensik. 2 ed. Yogyakarta: Universitas Gajah Mada Press; 2010. 1,59-60.

13. Petisa TP, Wulan AJ, Rodiani. Korelasi panjang tulang humerus terhadap tinggi badan pada pria suku Bali di Universitas Lampung. Medula. 2019;9(1):53-6.

14. Winarno IN, Carolia N, Wulan A. Korelasi panjang jari telunjuk tangan terhadap tinggi badan pria dewasa suku Bali dan suku Batak di Kecamatan Tanjung Senang Bandar Lampung. Medula. 2016;8(2):94-9. 